\title{
THE RESEARCH OF SELF-REGULATE SKILLS DEVELOPMENT THROUGH THE INFORMATION TECHNOLOGIES BY MEANS OF GEOGRAPHICAL CURRICULUM
}

\author{
Darina FOLTÝNOVÁ
}

\begin{abstract}
The paper is focused on the questions of self-regulation and possibilities of its development through the information technologies. The author's main aim was to suggest the way how to diagnose level of self-regulate skills development by pupils of basic school and to check by the experimental method whether teaching using information technologies supports self-regulate skills development.

The sense of the research was to offer the new idea for how to transfer questions of self-regulation through information technologies into the concrete situations in geography teaching so that pupils have the opportunity to look in their thinking and cognitive procedures. The results prove that it is possible to draw the geography teaching so that pupils use information technologies along with the geographical knowledge with the aim of to achieve required self-regulate skills development.
\end{abstract}

Key words: self-regulation, self-regulate skills, experimental method, information technologies, geography teaching.

\section{VÝZKUM ROZVOJE AUTOREGULAČNÍCH DOVEDNOSTÍ PROSTŘEDNICTVÍM INFORMAČNÍCH TECHNOLOGIÍ NA PŘÍKLADU ZEMĚPISNÉHO UČIVA}

Resumé: Předkládaný př̀spěvek se zabývá problematikou autoregulace a možnostmi jejího rozvoje prostřednictví informačních technologií. Autorka si kladla za cíl navrhnout způsob diagnostiky úrovně osvojení autoregulačnich dovedností u žáků druhého stupně základni školy a experimentální metodou ověrit výuku spočivajicí v nácviku autoregulačnich dovedností s využitím informačních technologií. Smyslem výzkumu bylo nabidnout námět pro prenesení problematiky rozvoje autoregulace prostřednictvím informačních technologii do konkrétnich úkolových situací v zemëpise tak, aby žáci dostali možnost a príležitost nahlédnout do svého myšleni a poznávacích postupů. Výsledky práce dokazují, že výuku zeměpisu lze koncipovat tak, aby žáci použivali informačni technologie zároveñ se smysluplným využívání geografických poznatků scílem dosáhnout žádoucí úrovně osvojení autoregulačnich dovedností.

Kličcová slova: autoregulace, autoregulační dovednosti, experimentální metoda, informační technologie, výuka zemépisu

\section{1 Úvod}

Cílem dnešní školy je naučit žáka nejen určitým vědomostem a dovednostem, ale především to, jak s nimi zacházet, jaké volit učební postupy, jak své učení plánovat, organizovat a řídit tak, aby se žáci obešli bez pomoci ostatních, aby byli odpovědni za své učení a motivování pro další celoživotní vzdělávání. Proces autoregulace, nebo-li proces řízení sám sebe při učení, je chápán jako určitý cíl či záměr, ke kterému má školní vzdělávání směřovat, jelikož schopnost autoregulovat své učení je základním předpokladem pro úspěšný život jedince $\mathrm{v}$ dnešní společnosti.

Důležitost informačních technologií (IT) pro budoucnost jednotlivce je zřejmá, a $z$ toho vyplývá významná role IT v rozvoji vzdělávání a celoživotního učení. IT mohou učitelům zvolením vhodných metod a postupů pomoci vést žáky k samostatnosti a k přebírání zodpovědnosti nad získáním potřebných vědomostí a dovedností. Žáci by se měli naučit pracovat s informačními technologiemi jako se zdroji dat tak, aby byli schopni samostatně informace nejen vyhledávat, trrídit a hodnotit, ale měli by umět s pomocí IT řešit problémy, komunikovat, vyjadřovat své názory a řešit úkoly a otázky týkající se např́íklad jejich nejbližšího prostředí.

\section{Teoretická východiska}

Vymezení pojmu autoregulační dovednosti

Termín autoregulace můžeme chápat jak z psychologického pohledu tak z pohledu pedagogické psychologie a didaktiky. Z psychologického pohledu autoregulace označuje „vztah člověka k sobě samému 
vyznačující se kromě sebepoznání také způsobilostí měnit a zdokonalovat sám sebe podle určitého plánu, utvářet sám sebe se zřetelem k určitým cílům, kterých má být dosaženo“ (Helus, Pavelková, 1992, s. 199). Z pohledu didaktiky a pedagogické psychologie se setkáváme ve vztahu s autoregulací se slovním spojením autoregulace učení, což lze volně chápat jako řízení vlastního učení nebo také ř́zení sám sebe při učení.

V anglicky psané literatuře lze spatřovat značné terminologické i věcné odlišnosti, které se liší jak v obsahu, tak v rozsahu a vzájemných vztazích mezi pojmy: self-regulated learning, self-directed learning, self-guided learning, selfmanaged learning nebo self-controlled learning (Mareš, Gavora, 1999).

V odborné literatuře se objevují v souvislosti s autoregulací různá slovní spojení. Terminologicky dochází knejednotnosti především v používání spojení autoregulačních strategií a autoregulačních dovedností, které je třeba diagnostikovat pokud chceme zjistit úroveň rozvoje autoregulace.

Pojem autoregulační strategie použili např́klad autoři Zimmerman a Martinez-Pons (1986, 1988), kteří ve svém výzkumu zjišstují, které autoregulační strategie učení používají žáci v různých učebních situacích. Celkem vytipovali 14 autoregulačních strategií a ověřovali pomocí strukturovaného rozhovoru jejich používání.

Termín autoregulační dovednosti (angl. selfregulated learning skills) je používán u mnoha českých i zahraničních autorů. V českých pedagogických či psychologických slovnících však vymezení tohoto slovního spojení nenajdeme. Při vymezování vycházejme z učebních dovedností. Dovednost lze např́klad chápat jako „učením získaná dispozice ke správnému, rychlému a úspornému vykonávání určité činnosti vhodnou metodou“ (Hartl, Hartlová, 2000, s. 121). Jinde je za dovednost považována ,způsobilost člověka k provádění určité činnosti“" (Průcha, Walterová, Mareš, 2001, s. 49) či ,způsobilost subjektu k řešení úkolových a problémových situací, která se projevuje pozorovatelnou činností" (Švec, 1998, s. 9). Dle uvedených definic dovednosti a autoregulace si dovolíme souhrnně a zjednodušeně označit autoregulační dovednosti jako určité způsobilosti člověka ř́́dit vlastní učení nebo také způsobilost řídit sám sebe při učení. V. Švec (1998) se ve své práci zabývá regulací a autoregulací procesu osvojování dovedností a uvádí, že za autoregulační dovednosti lze považovat dovednosti subjektu řídit průběh vlastního učení se dovednostem.

$\mathrm{V}$ předkládaném výzkumném šetření vycházíme $\mathrm{z}$ autoregulačních dovedností, které ve své teorii a modelu autoregulace klasifikuje B. Zimmerman (2002). Jedná se o následující autoregulační dovednosti: stanovení vlastních cílů; osvojení strategií pro dosažení cíle; efektivní řízení času, plánování, instruování; monitorování výkonu k označení pokroku; rekonstrukce kontextu za účelem kompatibility s cíli; sebehodnocení vlastních metod; atributy plynoucích prríčin; přizpůsobení budoucích metod, reakce, adaptace.

\section{Problematika autoregulace v geografickém vzdělávání}

Geografie se jako vědecká disciplína zařazuje mezi skupinu věd o Zemi, avšak svým objektem, jejímž je geografická sféra Země, nelze geografii zcela jednoznačně zařadit mezi vědy prŕrodní ani společenské. Tento interdisciplinární charakter oboru je třeba zohledňovat nejen při aplikaci geografických poznatků do jiných disciplín, ale predevším při aplikaci těchto poznatků do vyučovacího procesu, zejména pak do zeměpisu jako vyučovacího předmětu.

Multidisciplinární záběr zeměpisu má ve školním vzdělávání svůj integrační a zároveň integrující význam, který otevírá učiteli možnost nejen řešit úlohy napříc vyučovacími předměty, ale i vhodně didakticky transformovat vzdělávací obsah vzhledem $\mathrm{k}$ rozvíjení poznávacích procesů a knácviku at' už kognitivních či metakognitivních postupů.

Získané praktické poznatky, nabyté vědomosti i dovednosti při osvojování zeměpisného učiva využivá člověk po celý život. Geografické znalosti pomáhají porozumět vlastním zkušenostem člověka $\mathrm{v}$ prostředí $\mathrm{s}$ cílem znát nejen, kde se vyskytují určité objekty, jevy a procesy, ale se snahou hledat odpovědi na to, proč se právě nalézají na daných místech, jak tam vznikaly a jak budou nadále ovlivňovat budoucí vývoj.

Geografické vzdělávání by mělo směřovat k dosáhnutí nejen obsahově zaměřených cílů (pro vyučovací předmět geografie (zeměpis) jsou cíle vzdělávání (angl. objectives) definovány v Mezinárodní chartě geografického vzdělávání IGU (dostupné z www: http://igu-cge.tamu.edu/), ale především $\mathrm{k}$ rozvoji klíčových kompetencí, jejíž součástí je také rozvoj schopností žáka „naučit se učit“", neboli autoregulovat své učení. Geografické poznatky úzce spjaté s realitou 
dávají učiteli prostor pro motivaci žáka $\mathrm{k}$ rozvíjení zmiňovaných schopností, $\mathrm{k}$ tomu, aby dokázal žák získané geografické vědomosti, dovednosti a postoje $\mathrm{v}$ určitém kontextu použít a rozvíjet také $\mathrm{v}$ kontextu jiném, budoucím.

Obsah geografického vzdělávání umožňuje učiteli za využití informačních technologií tvořit nejrůznější otevřené úkoly, jejichž podstatou je, aby žáci dostávali př́ležitost $\mathrm{k}$ výběru, mohli vyvinout vlastní iniciativu při řešení problémů, mohli sami rozhodovat a uvědomovali si efektivitu vlastní práce. Geografické vzdělávání by mělo být učiteli konstruováno s pomocí informačních technologií tak, aby se žáci učili aktivně, aby jim byly vytvářeny př́ležitosti při rozhodování o jejich učení. Učitelé zeměpisu by měli zaujímat konstruktivní př́stup a vytvářet takové podmínky, ve kterých by výše uvedené elementy a předpoklady úspěšného učení byly prioritní.

Informační technologie k rozvoji autoregulačních dovedností

Informační technologie v současném světě prodělávají nebývalý rozvoj. Je nezbytné, aby na tuto skutečnost reagovala také dnešní škola. Je třeba si uvědomit důležitost IT pro budoucnost jednotlivců i celého lidstva a $z$ toho vyplývající významnou roli v rozvoji vzdělávání a celoživotního učení.

Počítačem podporovanou výuku zeměpisu lze charakterizovat jako vyučovací proces, v němž žáci individuálně, ve skupinách nebo $\mathrm{v}$ týmu využívají počítačovou techniku, výukové programy nebo Internet k vyhledávání informací, ke geografickému zkoumání nebo komunikaci. Informační technologie mohou učitelům zvolením vhodných metod a postupů pomoci vést žáky $\mathrm{k}$ samostatnosti a $\mathrm{k}$ přebírání zodpovědnosti nad získáním potřebných vědomostí a dovedností. Žáci by se měli naučit pracovat s informačními technologiemi jako se zdroji dat tak, aby byli schopni samostatně informace vyhledávat, třídit a hodnotit. Měli by umět řešit problémy, komunikovat, vyjadřovat své názory a řešit geografické otázky. Díky integrující úloze zeměpisu lze využít IT při projektové výuce $\mathrm{k}$ řešení aktuálních problémů $\mathrm{v}$ prostř̌edí.

Při implementaci informačních technologií do výuky zeměpisu (stejně tak jako i do ostatních předmětů) se samozřejmě setkáváme s řadou problémů (materiální vybavenost, didaktické a informační kompetence učitele atd.). Důležité je však uvědomit si efektivitu využívání IT s ohledem na obsah a cíle vzdělávání, kterých má být dosaženo. Pro učitele je tedy nutné nejdřive stanovit, co má být výukou s podporou IT naučeno a dále se pak učitel může zabývat otázkou, jak těchto cílů dosáhnout za přispění IT a kolik času bude $\mathrm{k}$ dosažení potřeba. Je nutné, aby si učitelé i žáci uvědomili, že výuka s podporou IT není pouze hrou, ale IT má být prostředkem k osvojení určitých vědomostí a dovedností.

\section{Výzkumné šetření}

\section{Obecné cíle výzkumu}

Teoretická východiska naznačili složitost problematiky autoregulace v kontextu geografického vzdělávání s využitím informačních technologií. $\mathrm{V}$ předkládaném výzkumném šetření bylo našim prvním cílem diagnostikovat úroveň osvojení autoregulačních dovedností u žáků druhého stupně základní školy, kteří mají nejlepší předpoklady $\mathrm{k}$ tomu, aby u nich byla autoregulace úspěšně rozvíjena (Mareš, 1998). Vzhledem k rozsahu a tematickému zaměření prríspěvku se nebudeme více touto první fází výzkumu zabývat (čtenár se více dočte viz Foltýnová, 2008). Konstatujme zde pouze důležitý závěr, který plyne z první fáze výzkumu a to ten, že většina žáků (74 \%) dosahuje úrovně pouze částečně osvojených nebo téměř neosvojených autoregulačních dovedností.

Druhým cílem bylo transformovat teoretické koncepty rozvoje autoregulačních dovedností s využitím informačních technologií do praktické realizace a výchovně vzdělávací praxe. Pokusili jsme se navrhnout a oveř̌it výuku dodržující zásady a principy nácviku autoregulačních dovedností. Cílem bylo odhalit jaké jsou rozdíly mezi vstupní a výstupní úrovní osvojení autoregulačních dovedností u jedinců po absolvování navrhnutého způsobu výuky.

\section{Metodologie výzkumu}

Vzhledem $\mathrm{k}$ charakteru problematiky výzkumného šetření se za nejvhodnější jevilo využít kvalitativně orientovaného výzkumu experimentální metoda rozvoje autoregulačních dovedností. V předkládaném šetření jsme řešili relační výzkumný problém, kdy jsme do vzájemného vztahu položili dvě proměnné a to autoregulační dovednosti (závisle proměnná) a systematický nácvik autoregulačních dovedností prostřednictvím informačních technologií (nezávisle proměnná). Metodou experimentu s využitím pretestu (resp. posttestu) jsme se pokusili odhalit, zda došlo ke zvýšení 
úrovně osvojení autoregulačních dovedností po záměrné intervenci.

\section{Použité metody sběru dat}

Pro dosáhnutí cíle stanoveného pro druhou fázi výzkumného šetření byla zvolena náročnější metoda experimentu, kde srovnáváme úroveň osvojení autoregulačních dovedností před (pretest) a po (posttest) záměrné intervenci. Ta spočívala $\mathrm{v}$ půlročním systematickém nácviku autoregulačních dovedností pomocí strategie generování otázek. Žáci převážně samostatně s využitím moderních informačních technologií (počítač, internet, tiskárna, geografické informační systémy atd.) zpracovávali geografické projekty.

Při tomto experimentálním postupu jsme využívali dotazník se škálovými otázkami pretest / posttest. Dotazník zjišt'oval úroveň osvojení autoregulačních dovedností po prvním (resp. posledním) absolvovaném projektu. Otázky se tedy vztahovaly ke konkrétnímu používání osmi autoregulačních dovedností. $\mathrm{Na}$ každou dovednost se bylo dotazováno třemi otázkami, kdy respondent hodnotil na škále stupeň svého souhlasu, resp. nesouhlasu s daným výrokem. Součástí výzkumného šetření byla také využita metoda analýzy dokumentů (ke každému geografickému projektu byly zkonstruovány pracovní listy), participační pozorování (v průběhu experimentu autorkapozorovatelka činila dlouhodobé účastnické skryté nestrukturované pozorování) a doplňující rozhovor s učitelem-pedagogem. Vyhodnocení získaných dat $\mathrm{z}$ analýzy dokumentů, z pozorování a $\mathrm{z}$ rozhovoru bylo součástí dalších fází výzkumného šetření (více viz Foltýnová, 2008).

\section{Výzkumný vzorek}

Pro experimentální šetření, byla využita dostupnost experimentální skupiny tvořené jedinci ze základního souboru, který $\mathrm{v}$ zájmu zachování konzistentnosti výzkumného vzorku s ostatními fázemi výzkumu, představují žáci 2. stupně ZŠ. Vzhledem k charakteru výzkumu bylo nezbytným předpokladem pro výběr experimentální skupiny prostředí, kde by bylo možno uskutečnit pravidelnou výuku $\mathrm{v}$ počítačové učebně, jelikož realizace experimentu předpokládá využití osobního počítače každým ze subjektu experimentu. Dostupný výběr tedy tvoří účastníci biologickozeměpisného kroužku, který tou dobou probíhal na ZŠ v obci Kr̆tiny (okres Blansko). Zeměpisný kroužek navštěvovalo celkem 15 žáků 7. a 8 . ročníku, kteří vykazovali shodné relevantní znaky nezbytné vzhledem k zaměření výzkumu.

\section{Výsledky výzkumu - srovnání úrovně osvojení autoregulačních dovedností před a po absolvování výuky s využitím informačních technologií}

V druhé fázi výzkumu jsme se pomocí experimentální metody pokusili zodpovědět otázku, zda systematický nácvik autoregulačních dovedností prostřednictvím informačních technologií vede k osvojení autoregulačních dovedností. V rámci tohoto výzkumného šetření jsme si kladli tři výzkumné předpoklady:

VP1: Systematický nácvik autoregulačních dovedností prostřednictvím informačních technologií vede ke zvýšení úrovně osvojení autoregulačních dovedností.

VP2: Existují interindividuální rozdíly v osvojení autoregulačních dovedností po absolvování výuky.

VP3: Změna mezi vstupní a výstupní mírou osvojení autoregulačních dovedností u žáků bude u jednotlivých autoregulačních dovedností signifikantně odlišná.

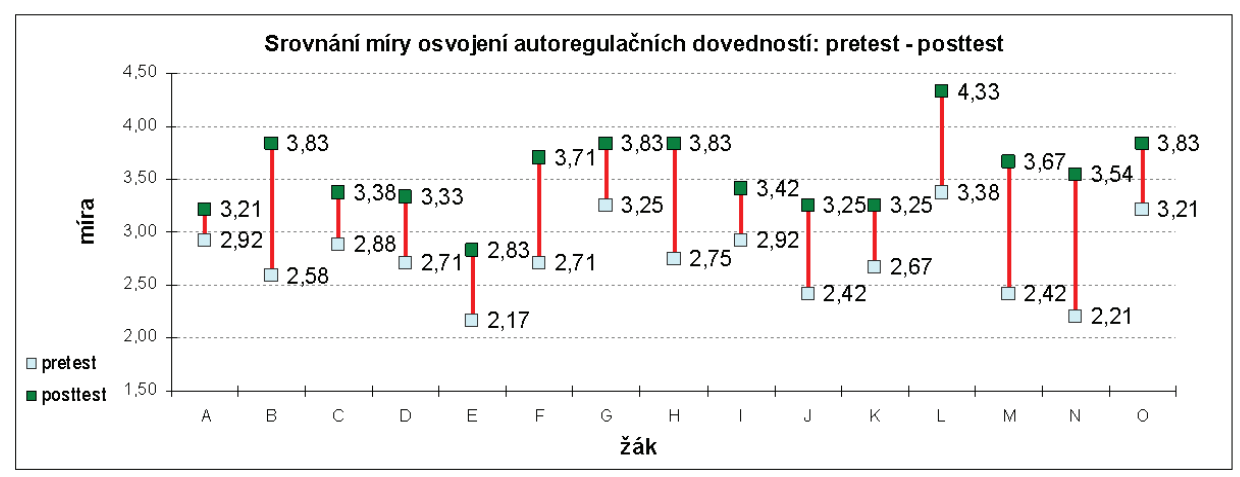

Obr 1: Srovnání míry osvojení autoregulačních dovedností v pretestu a posttestu 
Pomocí t-testu byl potvrzen výzkumný předpoklad VP1, že systematický nácvik autoregulačních dovedností prostřednictvím informačních technologií vede $\mathrm{k}$ osvojení autoregulačních dovedností. Na základě tohoto výpočtu byla porovnána úroveň osvojení autoregulačních dovedností u žáků $\mathrm{v}$ pretestu a posttestu (obr. 1) a došli jsme $\mathrm{k}$ závěru, že i když byly prokázány interindividuální rozdíly (byl potvrzen výzkumný předpoklad VP2), všichni zkoumaní žáci po absolvování výuky zvýšili své osvojení autoregulačních dovedností minimálně o jednu úroveň.
Při porovnávání jednotlivých dovedností (viz obr. 2) byl prokázán po absolvování výuky největši pokrok $\mathrm{v}$ míře osvojení dovedností stanovení cílů a sebehodnocení vlastních postupů a metod. Naopak nejmenší změnu v míře osvojení vykazovala dovednost související se způsobilosti zvládat úkol, dovednost osvojit si strategie pro zvládnutí úkolu a dovednost kontrolovat a měnit průběh za účelem dosáhnutí požadovaných cílů. Změna $\mathrm{v}$ míře osvojení jednotlivých autoregulačních dovedností mezi pretestem a posttestem byla tedy odlišná (byl potvrzen výzkumný předpoklad VP3).

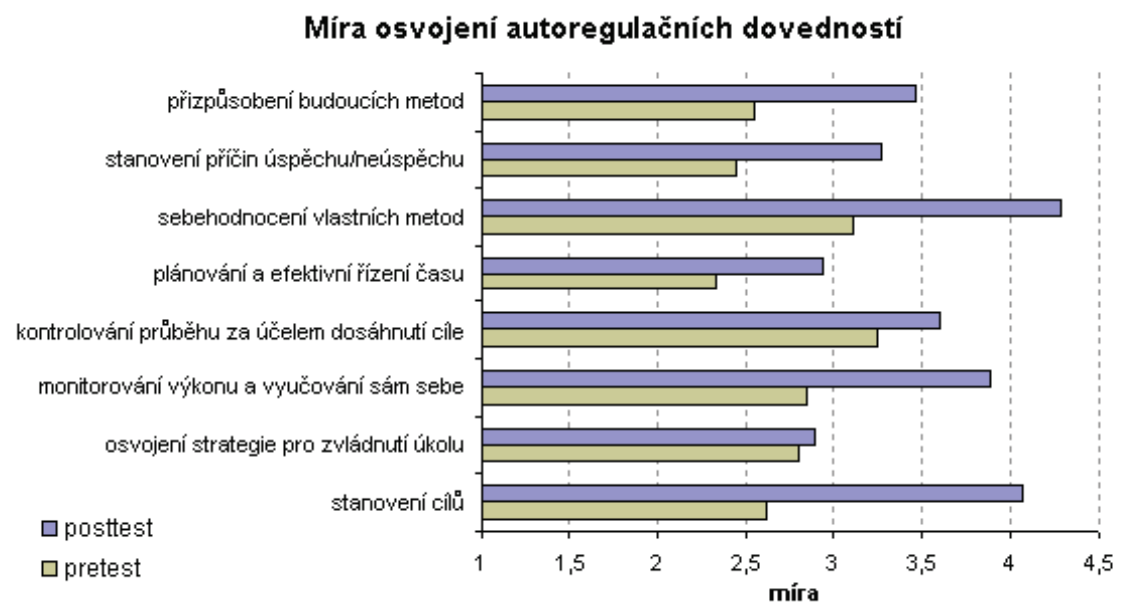

Obr 2: Míra osvojení jednotlivých autoregulačních dovedností

Ve výzkumném šetření jsme se snažili zamezit tomu, aby závěry byly ovlivněny jinými (rušivými) proměnnými. Díky specifickým podmínkám jsou výsledky získané v této fázi výzkumu omezeny pouze na zkoumané prostředí a vybrané jedince. Složitost navozené situace neumožnila uskutečnit experiment na větším výzkumném vzorku (či prípadné opakování experimentu), přesto shledáváme zjiššené výsledky za velmi př́nosné, jelikož nám umožnili jednak hlubší vhled do zkoumané problematiky, ale především dokládají možnost rozvoje autoregulačních dovedností u žáků druhého stupně základní školy.

\section{Závěry}

Při snaze implementovat proces autoregulace do výuky je třeba brát $\mathrm{v}$ úvahu reálné podmínky škol, možnosti učitelů i potencialit žáků. Otázkou zůstává způsob zařazení informačních technologií do výuky tak, aby byly u žáka prostřednictvím IT rozvíjeny autoregulační dovednosti a jejich použivání se stalo součástí každodenního života žáků. Vzhledem ke koncepci tvorby školních vzdělávacích programů však usuzujeme, že je nezbytné, aby důraz na osvojování a rozvíjení autoregulačních dovedností u žáků byl kladen ve všech vyučovacích předmětech. Opačný př́stup, ve kterém by těžiště osvojování autoregulačních dovedností prostřednictvím IT bylo soustředěno pouze $\mathrm{v}$ jediném předmětu, je podle našeho názoru jednak nereálný a jednak by nesplňoval principy, které jsou nezbytné pro úspěšný rozvoj autoregulace.

Klíč $\mathrm{k}$ rozvoji autoregulace a potenciálně také k využívání IT leží jednak v profesním rozvoji učitele, ale také v tvorbě podpůrných materiálů. Nejdůležitější a nezbytný moment tkví především ve změně postojů učitelů. Zde se domníváme, že největší problém pramení především v nedostatečné informovanosti, neznalosti a $\mathrm{v}$ nízkém přesvědčení učitelů $\mathrm{o}$ důležitosti a nezbytnosti rozvoje procesu autoregulace u žáků.

Žáci i učitelé musí aktivně přijmout osvojování autoregulačních dovedností jako metodu, kterou budou uplatňovat napríklad 
prostřednictvím informačních technologií a s plným uvědoměním ji dále rozvíjet.

Úloha především oborových didaktiků nespočívá jenom v koordinaci, integraci či $\mathrm{v}$ transformaci odborných poznatků do vyučovacího procesu, ale také $\mathrm{v}$ pomoci při realizaci kurikulární reformy. V této souvislosti se domníváme, že předkládané výzkumné šetření je plně v souladu s novým pojetím kurikula. Cílem základního vzdělávání je nejen to, aby žáci získali potřebné vědomosti, ale důraz je kladen také na rozvoj praktických dovedností práce s moderními informačními technologiemi, osvojení si potřebných strategií učení, motivování žáků pro celoživotní učení, podněcování žáků $\mathrm{k}$ tvořivému myšlení, k logickému uvažování, $\mathrm{k}$ řešení problémů či k rozvíjení schopnosti spolupracovat. Navrhnutý způsob výuky a zvolené metody prezentované v tomto př́spěvku plně odpovídají novým kurikulárním koncepcím.

\section{Literatura}

[1] FOLTÝNOVÁ, D. Vliv metakognitivních strategií na rozvoj dovedností žákủ autoregulovat své učení při osvojování zeměpisného učiva. Disertační práce. Brno: Masarykova univerzita, 2008.

[2] HARTL, P., HARTLOVÁ, J. Psychologický slovník. Praha : Portál, 2000, s. 121. ISBN 807178-303-X.

[3] HELUS, Z., PAVELKOVÁ, I. Vedení žáků ke vzdělávací autoregulaci a humanizaci školy. Pedagogika, 1992, roč. 42, č.2, s. 197-208. ISSN 3330-3815.

[4] MAREŠ, J., GAVORA, P. Anglicko-český pedagogický slovník. Praha : Portál, 1999. ISBN 80-7178-310-2.
[5] PRŮCHA, J., WALTEROVÁ, E., MAREŠ, J. Pedagogický slovník. Praha: Portál, 2001. ISBN 80-7178-579-2.

[6] ŠVEC, V. Klíčové dovednosti ve vyučování a výcviku. Brno: Masarykova universita,1998, s. 9. ISBN 80-210-1937-9.

[7] ZIMMERMAN, B. J.; MARTINEZ-PONS, M. Development of a Structured Interview for Assessing Students' Use of Self-regulated Learning Strategies. American Educational Research Journal, 23, 1986, s. 614-628. ISSN 0002-8312.

[8] ZIMMERMAN, B. J.; MARTINEZ-PONS, M. Construct Validation of a Strategy Model of Student Self-regulated Learning. Journal of Educational Psychology, 80, 1988, s. 284-290. ISSN 0022-0663.

[9] ZIMMERMAN, B. J. Becoming a selfregulated learner : An overview. Theory into practice. Columbus, 2002. ISSN: 1543-0421 (online). ISSN 0040-5841 (print).

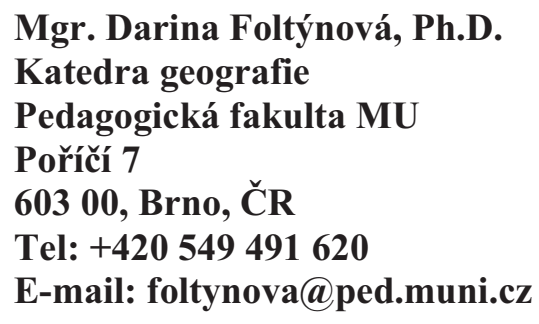

